\title{
An Analysis of Politeness Strategies in Sitcom Tetangga Masa Gitu from NET TV
}

\author{
I N Fatimah ${ }^{1 *}$ and Risa Rumetha Simanjuntak ${ }^{2}$ \\ English Department, Faculty of Humanities, Bina Nusantara University, Jakarta, Indonesia \\ *Corresponding author email: risaretha@gmail.com
}

\begin{abstract}
The aim of this research is to figure out politeness strategies which is used by four character in the sitcom. The tool of analysis mainly used is Brown and Levinson^s (1987) theory of politeness. Furthermore, the research method in this study using qualitative method and the writer are gathered the related theories using library research. The material that the writer used is sitcom TetanggaMasaGitu, which is a sitcom on NET TV. Brown and Levinson^s (1987) theory of politeness strategy towards four characters or two couples in this sitcom is a focus on this research. The result in this study, the writer finds several kinds of strategies politeness in each character, the differences politeness used by each couple, and also, the factors influence each couple of using those politeness strategies.
\end{abstract}

Keywords: Politeness Strategies, Sitcom, Tetangga Masa Gitu, NET TV

\section{INTRODUCTION}

Language is major tool for communication. In communication, we often miscommunication between speaker and listener, so, we can learn speaker meaning in pragmatics. Pragmatics is study of meaning as communicated by speaker and listener[1]. For example, someone says "It's hot in here", it means that person giving information that the weather is hot, or it can be means that he/she feels hot, the words can be have some meaning depends on the hearer get from the utterance. People who involved in interaction indirectly make the norms and principles that arise in the community as their politeness standards[1].

Politeness is about behaviour communicating in interaction. Politeness is not only about the content of conversation, but also the way conversation is managed and structured by the utterance. Politeness, in an interaction, can mean employed to show awareness of another person's face. Face in here means 'an individual's self-esteem'. Self-esteem is the need of every individual to be respected in front of the public situation. For example, "Could you lend me a pen?" the speaker means to borrow a pen, if the speaker is not really close to the addressee, the speaker may say politely. If uttered by different speaker, may be saying very different meaning. If the speaker is closer to listener, it may say impolite, even off record. For more details, the definition will be more explained in chapter two, which writer will explain more about the theory.
For this analysis, the writer will discuss the differences of politeness that are used of the couples in sitcom TetanggaMasaGitu Net TV which has unique characterization of four main characters. The study will offer different aspect of politeness as seen in situational comedy, reflecting how two different couples with different background interact and use politeness strategies. Such approach is different compare to the previous studies.

The writer wants to discuss more about the politeness strategies which are used in the sitcom. The writer finds out the politeness strategy by the dialogues. Each character has unique and different characterization, it means, each character use politeness differently in their communication. Politeness which is used by couple who longmarried and couple who has just married in sitcom and differences of their politeness interesting to analysed. The writer also wants discuss the factors influence their politeness strategy. What the factors behind their communication are, why they use different politeness strategies to others and to the other people are. In this study, the writer uses theory of politeness strategies [2]. Since their theory are so popular about politeness strategies. According to this theory by Brown and Levinson, politeness strategies divided into, positive politeness strategy, negative politeness strategy, Off Record, Bald-On Record, Mitigating Device, and Say Nothing[2] 
In Brown and Levinson's model, there are five strategies we can choose to avoid or weaken the FTA. The strategies are given below.

Politeness Strategies

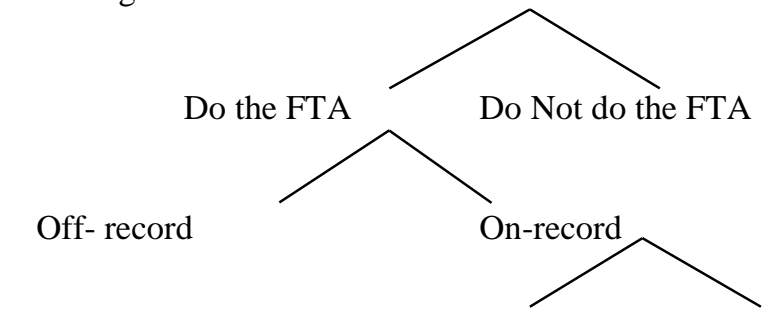

Without redressive action

Withredressive action (Baldly)

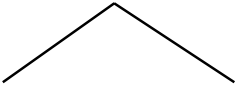

Positive Politeness Negative Politeness

FIGURE 1. Brown and Levinson's (1987)

Brown and Levinson emphasize on factors that influenced the use of politeness strategies. These factors foresee the social factors namely age, gender, and nationalities[3]. The social factors may influence the use of politeness strategies. Meanwhile, Brown and Levinson identify other dimensions that are power, distance and imposition.

Factors as well as social dimensions could also be identified through conversations [4]. The social perceptions underlying participants' interpretation and performance of communicative action fall within the area of sociopragmatics and refer to speakers' and hearers' social distance and social power, their respective rights and obligations and the degree of involved particular communicative acts. The identification of social roles and stereotypes, power relations between interlocutors relating to age, social status, or dialect, socio culturally based evaluations of situations, and linguistic value judgments have been typically considered social variables and have traditionally concerned sociolinguistic research. The social distance between interlocutors and relatives, culturespecific rights and obligations of interlocutors to each other in specific situations[5]. Previous studies have discussed the politeness strategies in several works of literature [6],[7].

\section{RESEARCH METHODS}

The research method that is applied in this research is qualitative research method through library research, because the data is gotten from the conversations by two couples in the sitcom. Furthermore, it is generally aimed to understand the speaker meaning, and understand speaker and listener attitudes while talking each other.

Tetangga Masa Gitu is a sitcom presents daily activity of two couples which live beneighbours. One couple who has been married about 10 years, they have neighbour, a couple who has been married in few days. This sitcom talks about the problems of household happened in daily life. Bastian Irawan and Bintang Howard Bonestain, a couple who just been married in few days full of romance in their house, while AdiPutranto and Angel Schweinteiger who has been married about ten years tend of realistic. In this research, the writer decides on sitcom Tetangga Masa Gitu Season 1. Tetangga Masa Gitu Season 1 has 52 episodes is chosen to be analysed in this research since there politeness strategies are used in this sitcom.

There are several steps that should be done to collect the data. First, find out the idea which is going to be analysed. After that, find the theory about politeness in pragmatics which can be used to analyse the study. Then, watch the sitcom Tetangga Masa Gitu Season 1 that there are 52 episodes to understand the plot and dialogues thoroughly. Next step is select and make the observation notes of the scenes and dialogues in sitcom which are going to be used as data. The last step is re-writing the dialogues of the sitcom scenes which has noted and already taken as the data to analyse politeness in the sitcom.

First thing to do is selecting the dialogues based on politeness strategies that are used by four main characters. Each type of politeness strategies is analysed based on the topic. And then, identify the strategies of politeness in the dialogues. Next, classify the strategies of politeness strategies of 
dialogues in sitcom. After that, finding out the factors influence politeness strategies in each couple.
The steps of conducting this research isseen in Fig.1:

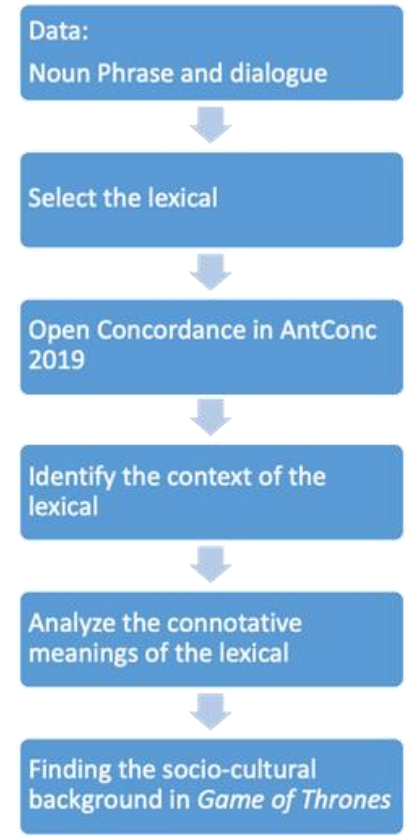

FIGURE 2. Research procedure

\section{RESULTS AND DISCUSSION}

Tetangga Masa Gitu Net TV is uniquely portraying two married couples' lives and communications. From the data there are nineteen (19) numbers of times when Bald-On Record strategies are used, and there are Off Record Strategies which used in seven (7) times, and also Positive Politeness Strategy used sixty-nine (69) times in this sitcom. Meanwhile, the characters use eight (8) times to use Negative Politeness, and the less of using Politeness Strategy is and Say Nothing five (5) times and Mitigating Device Strategy four (4) times. The most frequent strategy being used is Positive Politeness Strategy. TABLE of Total of Politeness Strategies is shown below:

TABLE 1. The use of Politeness Strategies

\begin{tabular}{|l|r|}
\hline \multicolumn{1}{|c|}{ Politeness Strategy } & Frequency \\
\hline Bald-On Record & 19 \\
\hline Off Record & 7 \\
\hline Positive Politeness & 69 \\
\hline Negative Politeness & 8 \\
\hline Mitigating Device & 4 \\
\hline Say Nothing & 5 \\
\hline
\end{tabular}

The differences between first couple, Adi and Angel, who have been married for ten years, with a new couple, Bastian and Bintang, who have been just married, showed totally different in this sitcom. The differences showed in their personality, their way face the problem, especially their communication to each other as a couple, and also communicate with the other people, especially with the neighbour.

Bastian Irawan use Positive Politeness Strategy the most. He use Positive Politeness to his wife, Bintang, his neighbour, Adi, or he usually call
Mr.Adi, and also he use Positive Politeness Strategy when talk to Angel, or he usually call Miss Angel. He sometimes use Negative Politeness Strategy, and Mitigating Devices. He sometimes use say nothing strategy, but he just use that strategy to Adi when Adi do weird things. Bastian there is once time, he used Negative Politeness when he spoke to Adi, we can see on excerpt nine (9), he felt bad to Adi when he could not give the ticket which Adi asked. And also, he used Negative Politeness when he talked to Ketua RT. It shows that he used the higher level of politeness than positive politeness. As mentioned in 
chapter 2 that Negative Politeness is higher level than Positive Politeness.

Bintang Howard Bonestain, who is a wife of Bastian has a unique character. She can control her behaviour in front of other people. She used Positive Politeness the most. While, Angela Schweinsteiger, wife of Adi who work as a lawyer, of course she knows how to speak right. She must be has been handle multiple clients and from various circles. In the home, who has been long live just both with her husband, Adi, she usually used the politeness strategy of bald-on record. However, she knows how handle her 'face' to other people. Even though she often used bald-on record to her husband, she never used that strategy when speak to other people even though she were going out with her husband. In some dialogues, she used bald-on record, positive strategy, mitigating device, negative politeness, she seldom used strategy of say nothing and off record. One of example, she used strategy say nothing, in excerpt 8, when she talked to Adi about free ticket from Bastian but Adi rejected it before he confirmed to Angel. She was really wanting to go the event, but Adi rejected the free ticket from Bastian, she got mad at him, so she forces him to got the ticket back but Adi did not want to do that. Finally, she say nothing and just do her gesture, put hands on hips, and her expression showed that she mad at him, and finally Adi scared of her, he agreed and try to get the ticket back.

AdiPutranto, this character is the most randomly using the politeness strategies. He usually used positive politeness strategy when talked to Bintang, but he can talked bald-on record when he talked to his wife, Angel, and Bintang's husband, Bastian, he also ever used bald-on record to Ketua RT. He also often off record strategy, and say nothing strategy. $\mathrm{He}$ seldom to talked used negative politeness strategy, and mitigating device. The writer got conclude that he is really an arrogant person, that he should not be face saving to talked to others.

In life, we cannot live alone or just with neighbours, same as in this sitcom, not only the conversation between two couples Adi-Angel and Bastian-Bintang, and their neighbours, Adi-Bastian or Adi-Bintang, even Angel-Bintang or AngelBastian, or contrarywise. However, many other people out there and of course, each characters make communication with them. It can be with friends in office, with the boss, with old friends, other neighbours, even other people, etc. When they meet one people to another, each character used different politeness.

One of example is one day, Ketua RT in their housing visited Bastian and Bintang's home. Ketua RT wanted to talk to Adi, Angel, Bastian and Bintang.Ketua RT wanted to give information to them about the event that would be held.There was conversation between them, Ketua RT, Adi, Angel, Bastian, and Bintang. During the conversation, we can see the politeness strategies are used by each character and the differences when they are talking. We also can see the differences politeness strategies they are used.

Ketua RT ever been a guest star in the sitcom. He came to give information to Bastian, Bintang, Adi, and Angel that around their housing will be held the contest which is involved all of the residents. During the conversation, Ketua RT the most polite than others, he used negative politeness and mitigating device. He also used positive politeness strategy, but it only shown once or twice. Over all, since he was that he the head of housing there, and he was talking to the resident (lower level than him), so he most used negative politeness and mitigating politeness.

The writer can conclude that the differences look so different when a woman talks to other woman, while the man talks to other man. On the other hand, we see the difference between a woman talks to a man, and when a man talks to or reply what woman said before.

From the TABLE, we can compare the different politeness strategies used between these two couples, Adi - Angel and Bastian - Bintang. First couple, Adi and Angel, use bald-on-record strategy the most, they also use positive politeness strategy. They use bald-on-record the most, because they feel that they have known each other for long time, they do not to show 'positive face' for to be accepted by others, do not be afraid that their couple in resentful, they show 'negative face' to be freedom and not imposed on their couple. They also use off record and say nothing strategy when someone gets angry to other. They show that they can express what they want to say, what they want to do. However, off record and say nothing are the least strategy are applied.

The second couple, Bastian - Bintang, they use positive politeness strategy the most. As a new couple, does not mean that they always use that politeness strategy, does not mean that they do not use bald-on-record strategy, off record, and so on. They also apply other strategies, but not much as positive politeness strategy. Positive politeness strategy is the base strategy which is used in politeness. Since they are a new couple, they use positive politeness with 'positive face' for liked, and does not want the partner hurt by his or her words.

Thus, all of the politeness strategies, there are say nothing, bald-on record, off record, mitigating device, positive and negative politeness. By comparing the six (6) strategies in politeness strategy, the first couple, Adi - Angel, use positive politeness and bald-on-record the most. While, 
Bastian - Bintang use positive politeness strategy the most. Adi - Angel use various politeness, Bastian Bintang just a few use other politeness.

Each character used different strategies of politeness, it can be depending on to whom the character talk to, on what situation, even their social. There are several factors which influence their using politeness strategy $[7,[8]$. These factors or social dimensions consisted of: Power, Distance, and Imposition[9],[10].

The Power relation discusses about the status between people in conversation. A person with high status of power is for example a boss talking to his subordinates. Talking to his/her subordinates, someone will likely use positive strategy to bald-on. A person with low power in conversation will use negative politeness strategy. Distance relation discusses about addressee's position in the society and age, social status, the relative power of the hearer over the speaker and vice versa $[11,[11]]$. The imposition is the weight of the action that threatens the addressee's autonomy and freedom of action [12].

\section{CONCLUSION}

Politeness is about behaviour communicating in interaction. Politeness is not only about the content of conversation, but also the way conversation is managed and structured by the utterance. This research brings up about theory politeness. This research has been done to analysed the politeness strategies which are used by each character in the sitcom.

After the writer has analysed the dialogues in each character, the writer found out that politeness strategy which used in sitcom Tetangga Masa Gitu NET TV the most is Positive Politeness Strategy. There are sixty nine times the character use this strategy, and the most use positive politeness strategy is Bastian and Angel, the other characters also use politeness strategy but they do not use as many as Bastian or Angel. Next strategy the most used is Bald-On Record Strategy. This strategy usually used by the old couple, Adi and Angel. Since Adi and Angel has been long-married, they feel really that should not to face saving in front of her husband or his wife. The third most used politeness strategy is Negative Politeness Strategy, the most use this strategy is Ketua RT who has ever been a guest star in this sitcom. Since he was that he the head of housing there, and he was talking to the resident (lower level than him), so he most used negative politeness and mitigating politeness. Some main characters also use this strategy, but they do not really much using this strategy. Three the least of used in politeness strategies in sitcom TetanggaMasaGitu are Off Record Strategy, Say
Nothing (do not do FTA) and the least used is Mitigating Device Strategy. Mitigating Device is the least of using politeness in this sitcom.

The way of communication can influence relation between speaker and interlocutor. The good relationship can be reached effectively if politeness strategy can be used exactly. This study can be reference for the next research. This research will help us to know which strategy that the speaker used the most. This research far from perfect, the writer hope that next writer who will research politeness strategies will be analysed better.

\section{REFERENCES}

[1] G. 1996. Yule, Pragmatics. Oxford: Oxford University Press. .

[2] S. 1978. Brown, P., \& Levinson, Universals in Language Usage: Politeness Phenomena. In E. Goody (Ed.), Questions and Politeness: Strategies in Social Interaction, pp. 56-310. Cambridge: Cambridge University Press.

[3] J. 2008. Holmes, Introduction to Sociolinguistics. Cambridge: Cambridge University Press. .

[4] L. 2009. Cumming, Pragmatics. Cambridge: Cambridge Universiity Press. .

[5] G. 2001. Ellen, A critique of Politeness Theories. Manchester, UK: St. Jerome. .

[6] Y. 2015. Huang, Pragmatics. Oxford: Oxford University Press. .

[7] Junita. 2013., Politeness Strategies and Socio-Cultural Impact Used by The Main Character in Alice's Adventures In Wonderland by Lewis Caroll. Jakarta: Bina Nusantara University. .

[8] G. 1983. Leech, Principle of Pragmatics. London: Longman. .

[9] S. 2003. Mills, Gender and Politeness. Cambridge: Cambridge University Press. .

[10] G. 1989. Myers, "The Pragmatics of Politeness in Scientific Articles. Applied Linguistics, 10(1), 1-35."

[11] T. 2014. Shalihah, Politeness Strategy in Daily Conversation of Betawinese Family. Jakarta: Bina Nusantara University. .

[12] E. 2009. Ogiermann, On Apologising in Negative and Positive Politeness Cultures. Amsterdam/Philadelphia: John Benjamins. . 